\title{
Antibacterial Activity of Electrochemically Activated Water Solutions on Pseudomonas aeruginosa after Four Weeks Storage
}

\author{
Teodora P. Popova* and Toshka E. Petrova \\ University of Forestry, Faculty of Veterinary Medicine, $10 \mathrm{Kl}$. Ohridski Blvd., \\ Sofia 1756, Bulgaria \\ *Corresponding author
}

\section{A B S T R A C T}

\begin{tabular}{|l|}
\hline K e y w o r d s \\
Antibacterial activity, \\
Anolyte, Catholyte, \\
Pseudomonas aeruginosa
\end{tabular}

Keywords

Antibacterial activity, Pseudomonas aeruginosa
Studies have been carried out to determine the effect of activated aqueous solutions (anolytes and catholytes) on multi-resistant strain of Pseudomonas aeruginosa in vitro after storage at room temperature. The solutions were obtained by electrochemical activation of water with $0.8 \% \mathrm{NaCl}$, and with a combination of $0.4 \% \mathrm{NaCl}$ and $0.4 \%$ $\mathrm{Na}_{2} \mathrm{CO}_{3}$. The disinfectant Virkon $\mathrm{S}$ was used as a control. Cultures were made on Cetrimide agar after different intervals of action of the solutions on $P$. aeruginosa suspensions $\left(10^{6}\right.$ cells $\left./ \mathrm{ml}\right)$. Anolytes and catholytes tested exhibited high antimicrobial activity. Upon potentiation of the anolytes by addition of $96 \%$ ethanol with a final concentration of $1 \%$, bactericidal activity was observed within 2 minutes. The use of catholyte of $\mathrm{NaCl}$ to dissolve Virkon $\mathrm{S}$ resulted in an increase in its effect compared to its use as an aqueous solution. After storage for 29 days, the solutions tested preserved their antibacterial properties to the maximum extent.

\section{Introduction}

The increasing prevalence of strains of pathogenic bacteria showing multiple resistance to antibiotics and also the rapid development of resistance to commonly used disinfectants are serious problems on a global scale. On the other hand, the pollution of the environment with chemical agents used to combat microorganisms in all spheres of human activity is growing. This leads to disturbance of the ecological balance and biodiversity in the nature. In recent years, the electrochemically activated aqueous solutions (EAASs) have been reported to be broadspectrum and environmentally safe biocidal products. The scope of their action includes not only bacteria but also spores, viruses and fungi. Gurgulova et al., (2010, 2011), Popova et al., (2016a, 2016c) and others found significant antibacteral activity of such solutions against Gram-positive and Gramnegative bacteria. Atanasov et al., (2014), Karadzhov et al., (2014) and other authors reported for antiviral activity of EAASs, and Tasheva et al., (2010) - for their antimycotic action. Antimicrobial effect of such solutions was found even in environments with high protein content such as biosludge (Dimitrova et al., 2013) and water from lagoons for storing bovine manure (Peev, 2017). The Gram-negative bacteria exhibit higher 
resistance to chemical factors than Grampositive ones primarily due to the protective properties of their outer lipoprotein envelope, as well as accelerated efflux of the toxic compounds. Among them, Pseudomonas aeruginosa is distinguished by particularly rapid adaptation to chemical factors and disinfectant solutions, as not only it does not perish in them but in many cases even multiplies. It is a causative agent of difficult to treat infections in humans and animals, as well as nosocomial infections. The increasingly common combination of antimicrobial multiresistance and enhanced virulence in this and the others causative agents of communicable diseases requires creativity in the development of prophylactic and therapeutic options (Alibert-Franco et al., 2009; Popova, 2016). EAASs can be a reliable perspective in this aspect. Recently, Popova et al., (2016a, $2016 \mathrm{~b}$ ) found high activity of anolyte of $\mathrm{NaCl}$ against $P$. aeruginosa.

Because the increasing isolation of multiresistant to antimicrobials strains of $P$. aeruginosa, the aim of this study was to investigate the possibilities of potentiating the action of electrochemically activated aqueous solutions by adding ethyl alcohol to increase their antimicrobial activity to this microorganism in vitro, as well as their effect after four weeks storage at room temperature.

\section{Materials and Methods}

\section{Anolytes}

Activation time - 12 min: - Anolyte prepared with $0.8 \% \mathrm{NaCl}$. Anolyte prepared with a combined solution of $0.4 \% \mathrm{NaCl}$ and $0.4 \%$ $\mathrm{Na}_{2} \mathrm{CO}_{3}$. Anolyte of $0.8 \% \mathrm{NaCl}$ potentiated by adding $96 \%$ ethanol to a final concentration of $1 \%$. Anolyte of a combination of $0.4 \%$ $\mathrm{NaCl}$ and $0.4 \% \quad \mathrm{Na}_{2} \mathrm{CO}_{3}$ potentiated by addition of $96 \%$ ethanol at a final concentration of $1 \%$.

\section{Catholytes}

Activation time - 12 min: - Catholyte prepared with $0.8 \% \mathrm{NaCl}$. Catholyte prepared with a combined solution of $0.4 \% \mathrm{NaCl}$ and $0.4 \%$ $\mathrm{Na}_{2} \mathrm{CO}_{3}$.

\section{Control}

The broad-spectrum disinfectant Virkon $\mathrm{S}$, applied at a final concentration of $0.5 \%$, was used as a positive control.

\section{Microorganisms}

A virulent strain of $P$. aeruginosa, isolated from a horse with clinical signs of acute sinusitis, was used. The isolation and identification were conducted in accordance with the international identifier of Bergey (Holt et al., 1994).

\section{Determination of the sensitivity of isolated bacteria to antimicrobial means}

It was done through the classic agar-gel diffusion method of Bauer et al., (1966) with standard antibiotic discs (BULBIO - NCIPD Ltd. - Sofia, Bulgaria).

The results were interpreted in the three-tier system of Bauer et al., (1966) after measuring the diameters of inhibitory zones in $\mathrm{mm}$.

\section{Nutritient media}

Media from BULBIO - NCIPD Ltd. - Sofia, Bulgaria were used: Mueller Hinton agar for preparation of 24-hour cultures of the bacterial strain and for determination of the sensitivity of isolated bacteria to antimicrobial means, Mueller Hinton broth for liquid cultures, as well as $P$. aeruginosa selective Cetrimide agar for isolation of the strain and determination of the antimicrobial activity of the tested solutions against this bacterial species. 
Determination of the antibacterial effect of the electrochemically activated aqueous solutions

Experiment 1. One $\mathrm{ml}$ of $P$. aeruginosa broth culture and $2 \mathrm{ml}$ of 3 -fold concentrated nutrient broth were added to $3 \mathrm{ml}$ of each EAAS (anolyte or catholyte). The achieved final concentration of EAAS was $50 \%$. Homogenization and culturing for 24-48 hours at $37^{\circ} \mathrm{C}$ followed.

Experiment 2. A suspension of $P$. aeruginosa at a concentration of $10^{7}$ cells $/ \mathrm{ml}$ in an amount of $1 \mathrm{ml}$ was added to $9 \mathrm{ml}$ of each EAAS (undiluted) tested, resulting in a final concentration of $10^{6}$ cells/ ml. After various time intervals of action of EAAS ( 2 min, 5 $\mathrm{min}, 10 \mathrm{~min}$ and $15 \mathrm{~min}$ ), cultures of each of the samples were made on Cetrimide agar and incubated at $37^{\circ} \mathrm{C}$ for $24-48 \mathrm{~h}$ under aerobic conditions.

The following controls were set in both experiments. - With application of the same concentration of the tested bacterial strain: sterile distilled water; distilled water with $1 \%$ $96^{\circ}$ ethanol; distilled water with $0.5 \%$ Virkon $\mathrm{S}$; catholyte with $0.5 \%$ Virkon S; catholyte without Virkon S; Mueller Hinton broth; Cetrimide agar. - Without microorganisms: the same variants, as well as $100 \%$ anolyte and $100 \%$ catholyte.

The EAASs used were stored for 29 days at room temperature in the dark and the experiments were repeated to assess to what extent they retained their activity.

Each experiment was performed in triplicate.

\section{Results and Discussion}

The physical indicators $\mathrm{pH}$, oxidation reduction potential (ORP) and temperature of the EAASs tested are presented in Table 1.
As can be seen from the table, the $\mathrm{pH}$ value was lowest in the anolyte of $\mathrm{NaCl}$ (2.47), and the highest - in the catholyte of $\mathrm{NaCl}$ and $\mathrm{Na}_{2} \mathrm{CO}_{3}$ (11.95), very similar to this of catholyte with $\mathrm{NaCl}$ (11.91). The highest ORP $(1000 \mathrm{mV})$ was measured in the anolyte obtained with $0.8 \% \mathrm{NaCl}$, followed by that with a combination of $\mathrm{NaCl}$ and $\mathrm{Na}_{2} \mathrm{CO}_{3}$ (439 $\mathrm{mV})$. In the catholytes, the lowest ORP was registered in that obtained with $0.8 \% \mathrm{NaCl}(-$ $368 \mathrm{mV}$ ), followed by the catholyte with a combination of $\mathrm{NaCl}$ and $\mathrm{Na}_{2} \mathrm{CO}_{3}(-323 \mathrm{mV})$. After 29 days of storage at room temperature, the change in $\mathrm{pH}$ of the solutions was negligible.

However, alterations were observed in values of their ORP, which were significantly lowered than those measured immediately after their preparation.

The results, presented in Table 2, show that the strain of $P$. aeruginosa was multi-resistant to antibiotics and sensitive only to certain aminoglycosides and quinolones.

The results of the investigations for antibacterial activity of EAASs against $P$. aeruginosa in broth and on Cetrimide agar are shown in Table 3 and some of them - in Figures 1 and 2. After storage of EAASs at room temperature for 29 days, these completely retain their antimicrobial activity. The data fully coincide with those established immediately after their preparation. It can be seen from the table that EAASs tested showed high antimicrobial activity even after 4 weeks of storage, which was the same as that on the day of their production.

From the data presented, it can be seen that the anolyte prepared with $0.8 \% \mathrm{NaCl}$, as well as that with $0.4 \% \mathrm{NaCl}$ and $0.4 \% \quad \mathrm{Na}_{2} \mathrm{CO}_{3}$ applied at a final concentration of $50 \%$ and $100 \%$, have a bactericidal effect on the multiresistant strain of $P$. aeruginosa. 
Table.1 Physical indicators of the anolytes and catholytes used

\begin{tabular}{|c|c|c|c|c|}
\hline \multicolumn{2}{|c|}{ Starting composition } & pH & ORP, $\mathbf{m V}$ & $t^{\circ} \mathrm{C}$ \\
\hline $\begin{array}{l}\text { Aqueous sodium chloride } \\
\text { solution } 0.8 \%\end{array}$ & $\begin{array}{l}\text { before electrolysis } \\
\text { anolyte - first day } \\
\text { after } 29 \text { days } \\
\text { catholyte - first day } \\
\text { after } 29 \text { days }\end{array}$ & $\begin{array}{c}8,92 \\
2,47 \\
2,52 \\
11,91 \\
11,42\end{array}$ & $\begin{array}{c}218 \\
1000 \\
263 \\
-368 \\
-146\end{array}$ & $\begin{array}{l}22,1 \\
20,7 \\
21,5 \\
20,7 \\
20,7\end{array}$ \\
\hline $\begin{array}{l}\text { Aqueous solution of sodium } \\
\text { chloride }(0.4 \%) \text { and sodium } \\
\text { carbonate }(0.4 \%)\end{array}$ & $\begin{array}{l}\text { before electrolysis } \\
\text { anolyte - first day } \\
\text { after } 29 \text { days } \\
\text { catholyte - first day } \\
\text { after } 29 \text { days }\end{array}$ & $\begin{array}{l}11,33 \\
10,74 \\
10,32 \\
11,95 \\
11,02\end{array}$ & $\begin{array}{r}109 \\
439 \\
193 \\
-323 \\
-238\end{array}$ & $\begin{array}{l}18,5 \\
20,6 \\
21,7 \\
19,7 \\
21,3\end{array}$ \\
\hline
\end{tabular}

ORP - oxidation-reduction potential

Table.2 Sensitivity of the isolated $P$. aeruginosa to antibacterial means in vitro

\begin{tabular}{|l|c|c|}
\hline Antimicrobial mean & Disc contents $(\mu \mathrm{g})$ & Sensitivity of the strain \\
\hline Thiamphenicol & 30 & $\mathbf{R}$ \\
Tetracycline & 30 & $\mathbf{R}$ \\
Lincomycin & 15 & $\mathbf{R}$ \\
Penicillin & 15 & $\mathbf{R}$ \\
Oxacillin & 1 & $\mathbf{R}$ \\
Amoxycillin+Clavulanic acid & 10 & $\mathbf{R}$ \\
Ampicillin & 10 & $\mathbf{R}$ \\
Cefuroxime & 30 & $\mathbf{R}$ \\
Cefotaxime & 30 & $\mathbf{R}$ \\
Kanamycin & 5 & $\mathbf{R}$ \\
Novobiocin & 30 & $\mathbf{R}$ \\
Gentamicin & 10 & $\mathbf{S}$ \\
Amikacin & 10 & $\mathbf{S}$ \\
Enrofloxacin & 5 & $\mathbf{S}$ \\
Ciprofloxacin & 5 & $\mathbf{S}$ \\
Sulfamethoxazole+Trimethoprim & $23,75 / 1,25$ & $\mathbf{I}$
\end{tabular}

$\mathrm{S}$ - sensitive; I - intermediate; $\mathrm{R}$ - resistant

Table.3 Antibacterial action of EAASs stored for 29 days - growth of $P$. aeruginosa in broth after exposure to $50 \%$ EAASs, and on Cetrimide agar after various intervals of exposure to undiluted EAASs

\begin{tabular}{|c|c|c|c|c|c|c|}
\hline \multirow[t]{3}{*}{ Sample№ } & \multirow[t]{3}{*}{ Type of activated solution } & \multirow{3}{*}{$\begin{array}{l}\text { Growth } \\
\text { in broth }\end{array}$} & \multicolumn{4}{|c|}{ Growth on Cetrimide agar } \\
\hline & & & \multicolumn{4}{|c|}{ Time of impact - min } \\
\hline & & & 2 & 5 & 10 & 15 \\
\hline 1 & anolyte of $\mathrm{NaCl}$ & - & - & - & - & - \\
\hline 2 & anolyte of $\mathrm{Na}_{2} \mathrm{CO}_{3}$ & - & - & - & - & - \\
\hline 3 & $1 \% 96^{\circ}$ ethanol in anolyte of $\mathrm{NaCl}$ & - & - & - & - & - \\
\hline 4 & $1 \% 96^{\circ}$ ethanol in anolyte of $\mathrm{Na}_{2} \mathrm{CO}_{3}$ & - & - & - & - & - \\
\hline 5 & $1 \% 96^{\circ}$ ethanol in distilled water & + & + & + & + & + \\
\hline 6 & $0,5 \%$ Virkon $\mathrm{S}$ in catholyte of $\mathrm{NaCl}$ & - & - & - & - & - \\
\hline 7 & $0,5 \%$ Virkon $\mathrm{S}$ in distilled water & + & - & - & - & - \\
\hline 8 & catholyte of $\mathrm{NaCl}$ & + & + & + & + & - \\
\hline 9 & catholyte of $\mathrm{Na}_{2} \mathrm{CO}_{3}$ & - & - & - & - & - \\
\hline $\mathbf{K}$ & untreated control & + & + & + & + & + \\
\hline
\end{tabular}

EAASs - electrochemically activated aqueous solutions 
Fig.1 Growth of P. aeruginosa on Cetrimide agar after treatment with undiluted EAASs. From left to right above: $1 \% 96^{\circ}$ ethanol in anolyte of $\mathrm{NaCl}(3-1,2) ; 1 \% 96^{\circ}$ ethanol in distilled water (5-2, 3); below: $0,5 \%$ Virkon $\mathrm{S}$ in catholyte of $\mathrm{NaCl}(6-3)$; catholyte of $\mathrm{NaCl}(8-1,2)$; untreated control $(\mathrm{k})$

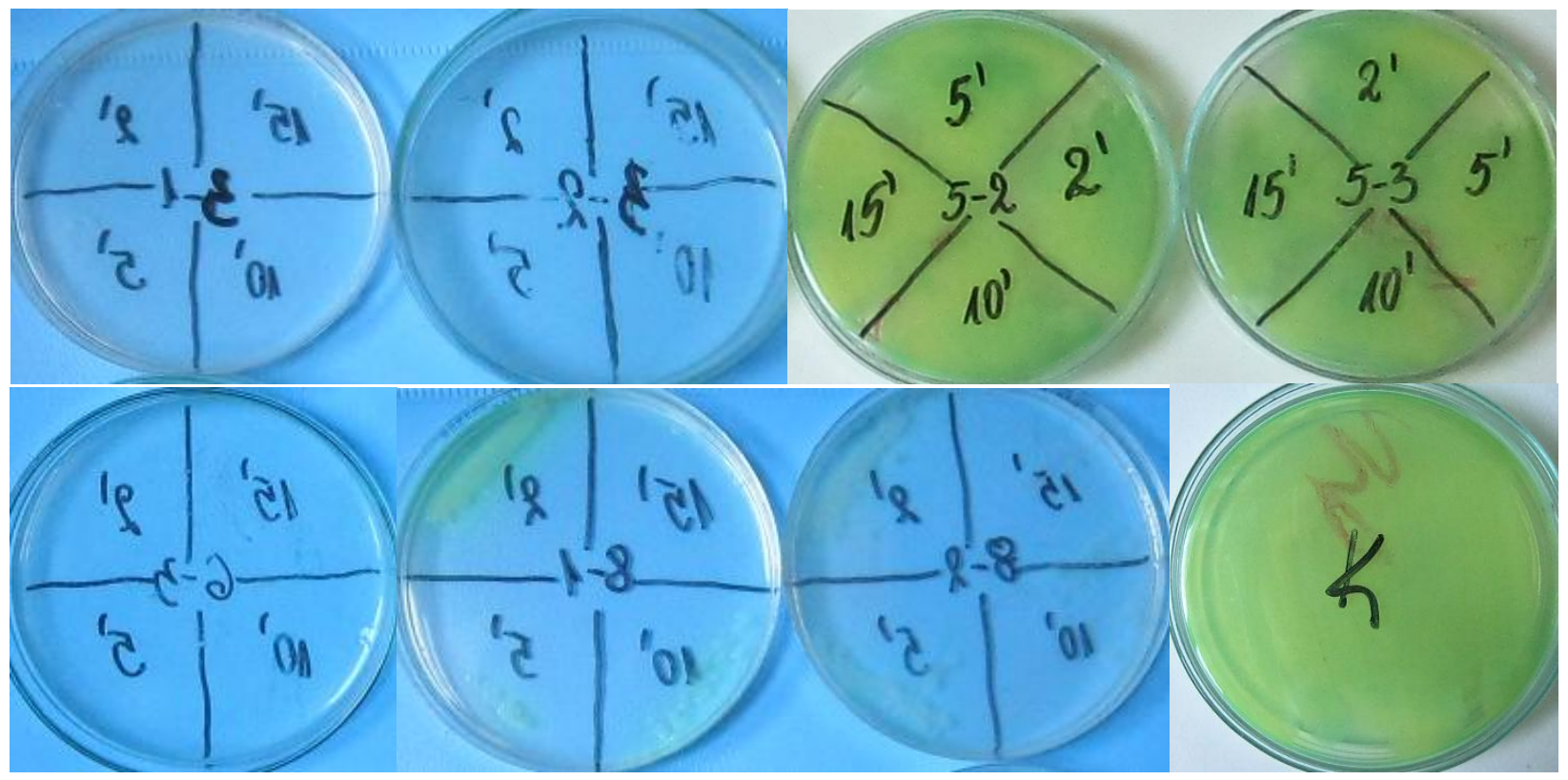

Fig.2 Growth of $P$. aeruginosa on Cetrimide agar after treatment with undiluted EAASs, stored for 29 days. Above: 1\% 96\% ethanol in anolyte of $\mathrm{NaCl}$ (3-1, 2 and 3); below: $1 \% 96^{\circ}$ ethanol in anolyte of $\mathrm{Na}_{2} \mathrm{CO}_{3}$ (4-1, 2 and 3)

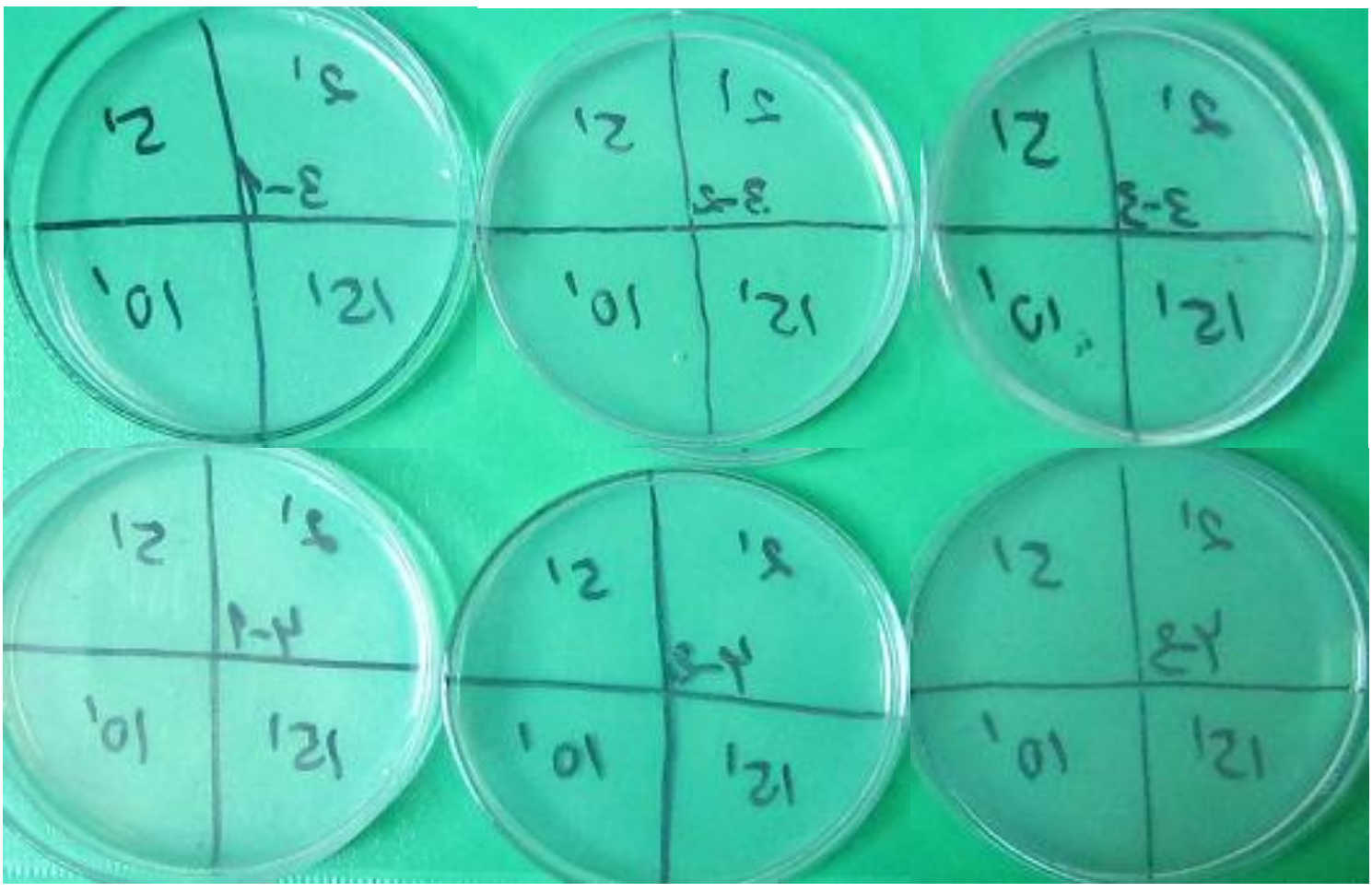


The same anolytes potentiated by the addition of $96 \%$ ethanol at a final concentration of $1 \%$ also have a rapid bactericidal action. Similar results were also found in samples with catholyte of $\mathrm{Na}_{2} \mathrm{CO}_{3}$. Under the influence of these five EAASs, $P$. aeruginosa died within 2 minutes as well as after administration of $0.5 \%$ Virkon $\mathrm{S}$ in catholite with $\mathrm{NaCl}$. When using $0.5 \%$ Virkon $\mathrm{S}$, dissolved in distilled water, however, growth was observed in some of the broth cultures of $P$. aeruginosa although colonies were not detected on the selective medium even after 48 hours of cultivation.

Our research categorically show that anolytes and catholytes activated with $0.8 \% \mathrm{NaCl}$, as well as with a combined application of $\mathrm{NaCl}$ and $\mathrm{Na}_{2} \mathrm{CO}_{3}$, can be used as antiseptics and disinfectants with great success even after storage at room temperature during a relatively long period of four weeks. This disinfection is fast, efficient and safe. In a comparative study of the disinfecting effect of anolytes with a starting composition of sodium chloride alone and a combination of sodium carbonate and sodium chloride, and some of the most commonly used antimicrobials, Gurgulova et al., (2011) indicated that the anolyte has biocidal properties similar to those of peracetic acid, and its high antimicrobial activity is combined with absolutely harmlessness to animals, humans and the environment. The activated substances with biocidal properties and with antimicrobial action against a wide range of microorganisms are formed during electrolysis in the process of preparation of EAASs. The substances resulting from the electrochemical treatment contained in them are in a metastable state for a time interval different for the anolyte and the catholyte, after which they revert to an inactive electrolyte state of the water. Because of their low oxidant content, the anolytes have very little chemical buffering, hence their environmental safety, both in their production and application, and after their intended use (Atanasov et al., 2014; Ignatov et al., 2015). Upon contact with the microbial cell, the EAASs cause its death mainly through the breakdown of the cell wall integrity, leakage of the intracellular components, violation of the ribosomal apparatus, coagulation of the cytoplasm, and others disabilities (Ashbakh, 2008; Bakhir, 2009a, 2009b).

According to the current studies, the antimicrobial activity of these EAASs can be potentiated by adding $96 \%$ ethanol in a final concentration of $1 \%$. The use of catholyte of $\mathrm{NaCl}$ to dissolve Virkon $\mathrm{S}$ is an opportunity for increasing its effect compared to its use as an aqueous solution. Data from our present studies show also that despite the change in the ORP of the tested solutions, which is essential for their antimicrobial activity, they retain this activity throughout the all studied period of 29 days. This is consistent with the results of our previous studies demonstrating that the antimicrobial activity of anolyte of $3 \% \mathrm{NaCl}$ is preserved even after storage for weeks at room temperature (Popova et al., 2016b). Obviously, except the ORP, a significant role for the antimicrobial activity of the solutions we investigated has and their hydrogen ion concentration, which was changed very little during the four week study period. Even at a concentration of $50 \%$, the anolytes and the catholyte of $\mathrm{Na}_{2} \mathrm{CO}_{3}$ are a sure means for safely decontaminating materials containing a virulent multi-resistant to antimicrobials strain of $P$. aeruginosa, even when the solutions are stored for four weeks.

Activated solutions are preparations, the mechanism of action of which is on a fundamentally new level - not chemically, as the usual drugs, but electrochemically. Accessible and not expensive apparatuses and technologies are used to obtain them. Therefore, it can be boldly said, that EAASs 
are a promising means of science-based medicine of the future.

Anolytes and catholytes obtained upon activation of water with $0.8 \% \mathrm{NaCl}$, as well as with a combination of $0.4 \% \mathrm{NaCl}$ and $0.4 \% \mathrm{Na}_{2} \mathrm{CO}_{3}$, exhibit high antibacterial activity on the tested multi-resistant strain of P. aeruginosa. After storage for 29 days, the electrochemically activated aqueous solutions tested preserved these antimicrobial properties to the maximum extent. Upon potentiation of the anolytes by the addition of $96 \%$ ethanol with a final concentration of $1 \%$ high bactericidal activity was observed within 2 minutes. The use of catholyte of $\mathrm{NaCl}$ to dissolve Virkon $\mathrm{S}$ resulted in an increase in its effect compared to its use as an aqueous solution.

\section{Acknowledgements}

This work was funded by the University of Forestry - Sofia with funds allocated of the State Budget for the implementation of Contract No B25/07.03.2018 for a scientific project on "Testing antimicrobial activity of an electrochemically activated aqueous solution anolyte".

\section{References}

Alibert-Franco, S., Pradines, B., Mahamoud A., Davin-Regli A., Pages J.-M. 2009. Efflux mechanism, an attractive target to combat multidrug resistant Plasmodium falciparum and Pseudomonas aeruginosa. CurrChem. 16 (3): 301-317.

Ashbakh, D. S. 2008. "Live and dead water the newest medicine of our time", Peter, St. Petersburg. ISBN: 978-5-38800190-0.

Atanasov, A., Karadzhov S., Ivanova E., Mosin O., Ignatov I. 2014. Study of the Effects of Electrochemical Aqueous
Sodium Chloride Solution Anolyte on the Virus of Classical Swine Fever Virus Mathematical Models of Anolyte and Catolyte as Types of Water. J Med, Physiol Biophys. 4: 1-26.

Bakhir, V. M. 2009a. Installation Aquachlor: Optimal system for water disinfection. III Scientific and Practical Conference "Modern Technologies of Water Treatment and Protection of Equipment against Corrosion and Scale Formation", Expocenter at Krasnaya Presnya, Moscow, 39-30 September, pp. 36-46.

Bakhir, V. M. 2009b. Fighting against microbes in water treatment and medicine: two sides of the same problem. Water Supp Sewerage. 9: 5868.

Bauer, A. W., Kirby W. M., Cherris J. C., Truck M. 1966. Antibiotic susceptibility testing by a standardized single disk method. The Am J Clin Pathol. 45 - 49: $493-496$.

Dimitrova, L., Kassovski V., Tzvetkova I., Hubenov V., Mihailova C., Simeonov I., Ivanov N., Gluhchev G., Naidenski H. 2013. "Bactericidal effect of electrochemically activated water on the aerobic bacterial population of biosylams". BAS, Project No DFNIE02/2013, Research Fund, Bulgaria.

Gurgulova, K., Georgieva T., Karadzhov S., Yordanov I., Atanasov G. 2010. "Biocidal action of electrochemically activated solutions (anolytes) against microorganisms responsible for rotten diseases in bee brood". NVS, Contract № 6 / 07.07.2010.

Gurgulova, K., Karadzhov S., Gogov Y., Georgieva T., Yordanov I. 2011. "Application in veterinary medicine of anolytes obtained by electrochemical activation of aqueous solutions of alkali and alkaline earth salts". Agricultural 
Academy, Anim Breeding Sci. XLVIII, $1 / 2011$.

Holt, J. G., Krieg N. R., Sneart P. H. A., Staley J. T., Williams S. T. 1994. Bergey's manual of determinative bacteriology, Ninth edition, Williams \& Wilkins.

Ignatov, I., Gluhchev G., Karadzhov S., Miloshev G., Ivanov N., Mosin O. 2015. Preparation of Electrochemically Activated Water Solutions (Catholyte/Anolyte) and Studying Their Physical-Chemical Properties. J Med, Physiol Biophys. 11: 1-21. ISSN 24228427 (Online).

Karadzhov, S., Atanasov A., Ivanova E., Mosin O., Ignatov I. 2014. Mathematical models of electrochemical aqueous sodium chloride solutions (Anolyte and Catholyte) as types of water. Study of the effects of anolyte on the virus of Classical swine fever. J Health Med Nurs (open access). 5: 30-55.

Peev, B. 2017. Study of the possibilities for accelerated composting of bovine manure. Dissertation work for awarding the educational and scientific degree "Doctor", Bulgarian Food Safety Agency, NDRVMI, Sofia, pp. 144-165.
Popova, T. 2016. Microbiology. Publishing house at FTU. Sofia, pp. 311.

Popova, T. P., Petrova T., Karadzhov S. 2016a. Investigation of the biocidal effect of electrochemically activated aqueous sodium chloride solution on Gram-negative pathogenic bacteria. Int J Curr Microbiol App Sci. 5 (1): 624632.

Popova, T. P., Petrova T., Karadzhov S. 2016b. Investigation of the action of the anolyte after different storage times on the Gram-negative bacteria. Int J Curr Microbiol App Sci. 5 (9): 530-539.

Popova, T. P., Petrova T., Karadzhov S., Krustanova G. 2016c. Investigation of the biocidal effect of electrochemically activated aqueous sodium chloride solution on Staphylococcus aureus. Traditions and Modernity in Vet. Med. (Sci. J. of FVM of UF, Sofia). 1 (1): 6772.

Tasheva, Y., Petkov Y., Karadzhov S. 2010. Test of the action of electrochemically activated aqueous solutions (anolytes) on Candida albicans. Proceedings of the FVM, UF, Sofia "Traditions and contemporaneity in Veterinary Medicine", pp. 152-158.

\section{How to cite this article:}

Teodora P. Popova and Toshka E. Petrova. 2018. Antibacterial Activity of Electrochemically Activated Water Solutions on Pseudomonas aeruginosa after Four Weeks Storage. Int.J.Curr.Microbiol.App.Sci. 7(10): 3379-3386. doi: https://doi.org/10.20546/ijcmas.2018.710.391 